\title{
Development of Guillain-Barré syndrome in a patient with multiple sclerosis during treatment with glatiramer acetate
}

\section{Zespót Guillaina-Barrégo u chorego na stwardnienie rozsiane leczonego octanem glatirameru}

Ewa Motta, Anna Gotba, Maciej Huć, Zofia Kazibutowska

Oddział Neurologii SPSK nr 7, Śląski Uniwersytet Medyczny w Katowicach

Neurologia i Neurochirurgia Polska 2012; 46, 2: 189-191

DOI: 10.5114/ninp.2012.28265

\begin{abstract}
Some observations suggest that in some patients with multiple sclerosis demyelination may affect the central and peripheral nervous systems at the same time. The influence of immunomodulatory therapy on peripheral nervous system damage in these patients is still unknown. We present a 43-year-old male patient with multiple sclerosis diagnosed at the age of 35 in whom flaccid tetraparesis with dysaesthesia preceded by paraesthesias of four limbs occurred one year after starting glatiramer acetate. The course of peripheral nervous system disease and results of cerebrospinal fluid examination and electromyography confirmed Guillain-Barré syndrome. Interfering in the immunological system, glatiramer acetate may have contributed to the development of the symptoms of Guillain-Barré syndrome in our patient. The final improvement of the patient's condition may have resulted not only from the applied treatment and the natural course of the disease, but may have also been associated with the discontinuation of glatiramer acetate.
\end{abstract}

Key words: Guillain-Barré syndrome, multiple sclerosis, glatiramer acetate.

\section{Introduction}

As early as in the second half of the $20^{\text {th }}$ century, it was supposed that demyelination may affect the central and peripheral nervous systems at the same time. The pro-

\section{Streszczenie}

W ostatnich latach zaobserwowano, że u niektórych chorych na stwardnienie rozsiane demielinizacja dotyczy także obwodowego układu nerwowego. Wpływ leczenia immunomodulującego na ten typ uszkodzenia pozostaje niejasny. W pracy przedstawiono przypadek 43-letniego mężczyzny, u którego stwardnienie rozsiane rozpoznano w 35. roku życia i u którego rok po rozpoczęciu leczenia octanem glatirameru wystąpiła nagle wiotka tetrapareza $\mathrm{z}$ zaburzeniami czucia. Badanie płynu mózgowo-rdzeniowego oraz badanie elektromiograficzne potwierdziły rozpoznanie zespołu Guillaina-Barrégo. Leczenie octanem glatirameru mogło się przyczynić do wystąpienia tego zespołu u opisywanego pacjenta. Uzyskana poprawa stanu chorego mogła być wynikiem stosowanego leczenia i naturalnego przebiegu choroby, nie można też pominąć znaczenia odstawienia glatirameru.

Słowa kluczowe: zespół Guillaina-Barrégo, stwardnienie rozsiane, octan glatirameru.

portion of multiple sclerosis (MS) patients in whom abnormalities in the electrophysiological examination of peripheral nerves were found varies considerably, from $5 \%$ to $74.2 \%$ [1-6]. In almost all the reports of changes in the examined peripheral nerves in MS patients, the da-

Correspondence address: dr Anna Gotba, Oddział Neurologii SPSK nr 7, Śląski Uniwersytet Medyczny, ul. Ziołowa 45-47, 40-635 Katowice, e-mail:sum.neurologia@op.pl

Received: 3.03.2011; accepted: 6.09.2011 
mage to those nerves was mostly demyelinating, and it was asymptomatic in most cases.

In the literature there are few cases of Guillain-Barré syndrome (GBS) occurring in patients with clinically definite MS [7]. In 2008, Sharma et al. [8] described five cases of chronic inflammatory demyelinating polyneuropathy (CIDP) which developed in MS patients. None of those patients was treated with interferon beta, so the possibility of inducing polyneuropathy by this drug was excluded. Ekstein et al. [2] described six cases of neuropathy caused by interferon beta in MS patients. Neuropathy receded in five patients after the discontinuation of this treatment, and the re-introduction of this drug caused the recurrence of neuropathy in two patients [2]. In the MS patients described by Pirko et al. [5], CIDP developed after 4 months, 1 year and 4 years, respectively from the beginning of treatment with interferon beta.

\section{Case report}

We report the case of a 43-year-old man with relapsing-remitting form of MS who developed GuillainBarré syndrome after one year of treatment with glatiramer acetate. The patient was diagnosed with MS at the age of 35. The disease course was relapsing-remitting with approximately one exacerbation each other year. The patient met revised McDonald's [9] criteria with both clinical presentation and additional examinations; magnetic resonance imaging of the brain showed multiple and mainly periventricular demyelinating lesions; visual evoked potentials were abnormal, cell count and protein level in cerebrospinal fluid were within the normal range. The patient was ambulatory with Expanded Disability Status Scale score of 2.0. Glatiramer acetate treatment was started in April 2007. In April 2008, the patient developed flaccid tetraparesis with lack of tendon reflexes (III/IV on Lovett scale) and polyneuropathic dysaesthesias preceded by paraesthesias of calf and feet.

Over the following few days, symptoms worsened to bilateral facial paralysis and flaccid paralysis of the lower limbs. These symptoms coincided with a respiratory tract infection (right-sided pneumonia) confirmed by $\mathrm{X}$-ray examination. The examination of the cerebrospinal fluid showed an increase in protein level (54 mg/dL) with cell count within the normal range. Electroneurographic examination showed signs of axonal demyelinating sensory motor neuropathy. Tests for ANA, dsDNA and anti-Borrelia antibodies were negative.
Neuroimaging examination of the head and the cervical spine did not show new active demyelinating lesions. The patient was diagnosed with Guillain-Barré syndrome. Treatment with glatiramer acetate was withdrawn. The patient received antibiotics and immunoglobulins at the dose of $0.4 \mathrm{mg} / \mathrm{kg} /$ day for five consecutive days. A significant improvement in the function of the limbs as well as a slight improvement of the electroneurographic parameters were achieved. Facial paresis persisted. The continued, several-month long rehabilitation of the patient brought further normalisation of the neurological condition and the electroneurographic findings.

\section{Discussion}

Glatiramer acetate consists of acetate salts of oligopeptides composed of four naturally occurring amino acids. Glatiramer acetate influences immune cells in an antigen-specific way. Administered chronically, it acts as an antigen-based therapeutic vaccine. Glatiramer acetate oligopeptides administered subcutaneously interact with antigen presenting cells and blood lymphocytes locally at the site of injection. The systemic immune response is mediated by circulating activated glatiramer acetatereactive $\mathrm{T}$ cells. Glatiramer acetate-specific Th2 cells cross the blood-brain barrier and, accumulated in the CNS, release anti-inflammatory cytokines inhibiting nearby immune cells (bystander suppression mechanism) [10-13]. Additionally, these Th2 cells secrete neurotrophic substances (e.g. brain-derived neurotrophic factor) which might mediate suggested glatiramer acetate neuroprotective activity. All patients treated with glatiramer acetate develop specific antibodies against the drug which reach peak levels after 3-6 months of therapy and then stabilize at low levels. Glatiramer acetate oligopeptides also stimulate peripheral blood lymphocytes; the initial Th1 pro-inflammatory response with repeated administration of glatiramer acetate switches to the Th2 anti-inflammatory type [14].

We have not found a description of the occurrence of Guillain-Barré syndrome in an MS patient treated with glatiramer acetate. There was however a successful trial to treat experimental autoimmune neuritis (which is an experimental model of Guillain-Barré syndrome in mice) with glatiramer acetate [15]. The mechanism in which glatiramer acetate might have contributed to the development of Guillain-Barré syndrome in our patient is uncertain. Cross-reaction of peripheral nerve myelin antigens with glatiramer acetate-speci- 
fic antibodies after one year of therapy is rather questionable. The patient suffered from pneumonia, which often precedes Guillain-Barré syndrome. It cannot be excluded that modulation of the immune system with glatiramer acetate treatment eased immunopathological processes which led to Guillain-Barré syndrome development. The improvement of the patient's condition may have resulted not only from the applied treatment and the natural course of the disease, but may have also been associated with the discontinuation of glatiramer acetate. One thing is certain in this case: glatiramer acetate treatment did not prevent Guillain-Barré syndrome development in our patient.

\section{Disclosure}

Authors report no conflict of interest.

\section{References}

1. Capello E., Roccatagliata L., Schenone A., et al. Acute axonal form of Guillain-Barré syndrome in a multiple sclerosis patient: chance association or linked disorders. Eur J Neurol 2000; 7 : 223-225.

2. Ekstein D., Linetsky E., Abramsky O., et al. Polyneuropathy associated with interferon beta treatment in patients with multiple sclerosis. Neurology 2005; 9: 456-458.

3. Frese A., Bethke F., Lüdemann P., et al. Development of myasthenia gravis in a patient with multiple sclerosis during treatment with glatiramer acetate. $J$ Neurol 2000; 247: 713.

4. Mendell J.R., Kolkin S., Kissel JT., et al. Evidence for central nervous system demyelination in chronic inflammatory demyelinating polyradiculoneuropathy. Neurology 1987; 37: 1291-1294.

5. Pirko I., Kuntz NL., Patterson M., et al. Contrasting effects of IFN-beta and IVIG in children with central and peripheral demyelination. Neurology 2003; 27: 1697-1699.

6. Weir A., Hansen S., Ballantyne J. Motor unit potential abnormalities in multiple sclerosis: further evidence for a peripheral nervous system defect. J Neurol Neurosurg Psychiatry 1980; 43: 999-1004.

7. Simonetti S., Capello E. Acute pure motor neuropathy with antibodies to gangliosides in a patient with multiple sclerosis. J Neurol 1998; 245: 617-619.

8. Sharma K.R., Saadia D., Facca A.G., et al. Chronic inflammatory demyelinating polyradiculoneuropathy associated with multiple sclerosis. J Clin Neuromuscul Dis 2008; 9: 385-396.

9. Polman C.H., Reingold S.C., Banwell M., et al. Diagnostic criteria for multiple sclerosis: 2010 revisions to the McDonald criteria. Ann Neurol 2011; 69: 292-302.

10. Dhib-Jalbut S. Mechanisms of action of interferons and glatiramer acetate in multiple sclerosis. Neurology 2002; 58: 3-9.

11. Wolinsky J.S. Glatiramer acetate for the treatment of multiple sclerosis. Expert Opin Pharmacother 2004; 5: 875-891.
12. Allie R., Hu L., Mullen K.M., et al. Bystander modulation of chemokine receptor expression on peripheral blood $\mathrm{T}$ lymphocytes mediated by glatiramer therapy. Arch Neurol 2005; 62 : 889-894.

13. Ziemssen T., Kümpfel T., Klinkert W.E., et al. Glatiramer acetate-specific T-helper 1- and 2-type cell lines produce BDNF: implications for multiple sclerosis therapy. Brain-derived neurotrophic factor. Brain 2002; 125: 2381-2391.

14. Brenner T., Arnon R., Sela M., et al. Humoral and cellular immune responses to Copolymer 1 in multiple sclerosis patients treated with Copaxone. J Neuroimmunol 2001; 115: 152-160.

15. Aronovich R., Katzav A., Chapman J. The strategies used for treatment of experimental autoimmune neuritis (EAN): a beneficial effect of glatiramer acetate administered intraperitoneally. Clin Rev Allergy Immunol 2012; 42: 181-188. 